\title{
Cherry Tomato Drying: Sun versus Convective Oven
}

\author{
Vincenzo Alfeo ${ }^{1}\left(\mathbb{D}\right.$, Diego Planeta ${ }^{1} \mathbb{1}$, Salvatore Velotto ${ }^{2, *}$, Rosa Palmeri ${ }^{3}$ and Aldo Todaro ${ }^{1}$ \\ 1 Dipartimento di Scienze Agrarie, Alimentari e Forestali-Università degli Studi di Palermo, \\ viale delle Scienze 13, 90128 Palermo, Italy; vincenzo.alfeo@unipa.it (V.A.); diego.planeta@unipa.it (D.P.); \\ aldo.todaro@unipa.it (A.T.) \\ 2 Department of Promotion of Human Sciences and the Quality of Life, University of Study of Roma, \\ San Raffaele, Via Val di Val Cannuta 247, 00118 Roma, Italy \\ 3 Dipartimento di Agricoltura, Alimentazione e Ambiente-Università degli Studi di Catania, via S. Sofia 98, \\ 95123 Catania, Italy; rpalmeri@unict.it \\ * Correspondence: salvatore.velotto@uniroma5.it; Tel.: +39-081-559-0043
}

Citation: Alfeo, V.; Planeta, D.

Velotto, S.; Palmeri, R.; Todaro, A.

Cherry Tomato Drying: Sun versus Convective Oven. Horticulturae 2021,

7, 40. https://doi.org/10.3390/

horticulturae7030040

Academic Editor:

Douglas D. Archbold

Received: 27 October 2020

Accepted: 24 February 2021

Published: 27 February 2021

Publisher's Note: MDPI stays neutral with regard to jurisdictional claims in published maps and institutional affiliations.

Copyright: (c) 2021 by the authors. Licensee MDPI, Basel, Switzerland. This article is an open access article distributed under the terms and conditions of the Creative Commons Attribution (CC BY) license (https:// creativecommons.org/licenses/by/ $4.0 /)$.

\begin{abstract}
Solar drying and convective oven drying of cherry tomatoes (Solanum lycopersicum) were compared. The changes in the chemical parameters of tomatoes and principal drying parameters were recorded during the drying process. Drying curves were fitted to several mathematical models, and the effects of air temperature during drying were evaluated by multiple regression analyses, comparing to previously reported models. Models for drying conditions indicated a final water content of $30 \%$ (semidry products) and $15 \%$ (dry products) was achieved, comparing sun-drying and convective oven drying at three different temperatures. After 26-28 h of sun drying, the tomato tissue had reached a moisture content of $15 \%$. However, less drying time, about $10-11 \mathrm{~h}$, was needed when starting with an initial moisture content of $92 \%$. The tomato tissue had high ORAC and polyphenol content values after convective oven drying at $60^{\circ} \mathrm{C}$. The dried tomato samples had a satisfactory taste, color and antioxidant values.
\end{abstract}

Keywords: antioxidant activity; drying process; tomato

\section{Introduction}

Drying vegetables is a very ancient practice for food preservation, and it is still in use nowadays. Sliced tomatoes (Solanum lycopersicum), with salt added and then dried, have been an important element of the culinary tradition in the south of Italy. Tomato drying is still carried out using a sun-drying process in Sicily, with an empiric method. The final product has a high but not a homogeneous quality.

Large-scale production has limits to the use of open-air natural sun drying. Among these are the lack of ability to control the drying process properly, weather uncertainties, high-cost of labor, large area requirements, and insect infestation [1]. Giovannelli and Paradiso [2] investigated tomato drying to assess the desorption isotherm and to analyze several mathematical models to interpolate the experimental data optimally. The results showed that the mathematical models of Oswin and Guggenheim-Anderson-de Boer $(\mathrm{GAB})$ had an average relative error (E\%) lower than other models considered. This result was supported by [2,3], where it was highlighted that the GAB model was the best interpolating model fitting all experimental points.

In order to find the best drying conditions, several authors have studied the effects of dipping tomato tissue in calcium chloride [4,5], sodium chloride $(\mathrm{NaCl})$ [6], sodium chloride and sucrose [7] and potassium carbonate solution [8]. However, Doymaz [9] analyzed the effect of dipping with alkaline ethyl oleate before drying at temperatures of 55, 60, 65 and $70^{\circ} \mathrm{C}$. The data were analyzed using different mathematical models to assess the kinetics of drying, and, according to the author, the Page mathematical model can be considered the most appropriate [10]. Though the primary objective of food drying is preservation, depending on the specific technique, the raw material may end 
up a completely different product with significant variation in quality. Drying causes oxidative damage due to the high temperatures and oxygen levels [2]. Several studies have investigated tomato antioxidant activity after drying in which it was hypothesized that the higher bioaccessibility of bioactive compounds, and the release of free phenolic hydroxyl groups, increased the antioxidant activity [11]. The same effects on antioxidant compounds were observed in dried onion (Allium cepa) powder, where the increase in antioxidant activity was associated with the activity of hydrolytic enzymes and enhanced the radical scavenging activity [12].

Nguyen and Schwartz [13] studied the effects of drying on tomato antioxidant compounds and showed that lycopene and carotenoids were substantially stable to industrial drying, but significant oxidative damage occurred during storage of the dried tomatoes [2]. Lycopene stability depends on both its heat resistance and the formation of Maillard reaction products that could act as pro- or antioxidants [14]. These compounds have been shown to act as antioxidants in dried foodstuffs, individually or in combination with naturally occurring antioxidants, since synergistic effects between antioxidants have been investigated [15,16]. Mrkic et al. [12] showed that high-temperature and short-duration drying processes maximized the antioxidant activity of broccoli by increasing the release of compounds from the matrix, hydrolytic phenomena which took place during drying, and polyphenol oxidation resulting in oligomers with higher antioxidant activity than the native compounds. Nevertheless, in this study, the evaluation of hydroxymethylfurfural (HMF) content did not support the hypothesis of a contribution of Maillard reduction products to antioxidant activity. Total lycopene content was directly connected to the drying temperature because the higher temperatures are, the more lycopene was extracted from the matrix [16,17].

Shi et al. [18] investigated lycopene availability during the drying process, highlighting an isomerization of the lycopene from the most active form, "trans", to the least active form, "cis". According to the author, this conversion, which stands at a value of $16 \%$, involves a decrease of lycopene bioactivity in dried products $[19,20]$.

Toor and Savage [16] and Toor et al. [17] carried out drying at $42{ }^{\circ} \mathrm{C}$ for $18 \mathrm{~h}$, monitoring lycopene, ascorbic acid and total polyphenol content. The lycopene content was comparable to the content of the fresh product. The total lycopene content was directly related to the drying temperature. Ascorbic acid content was lower than in the fresh product because of its thermosensitivity $[2,19,21]$. The total polyphenol content was reduced due to polyphenol oxidase (PPO) activity that, with high probability, was not inactivated by the drying temperature $\left(42{ }^{\circ} \mathrm{C}\right)$. Spagna et al. [22] monitored the PPO activity in fresh tomatoes. The PPO activity fell significantly above $50{ }^{\circ} \mathrm{C}$, showing an optimum at $40{ }^{\circ} \mathrm{C}$ with $55 \%$ of activity at cold storage temperatures $\left(4^{\circ} \mathrm{C}\right)$. The enzyme is sensitive to the presence of high concentrations of $\mathrm{NaCl}$. The results are supported by the evidence reported by Dewanto [19] in which the variation of the total polyphenol content, after heat treatment at $80^{\circ} \mathrm{C}$ for $30 \mathrm{~min}$, was negligible.

Drying also has effects on amino acid content. Significant losses in amino acids occur during tomato processing, and the extent of degradation is correlated to the severity of heat and oxidative stress [2,23]. Total phenolic content increased due to drying, and the increase was proportional to drying severity. Air drying did not cause significant changes in rutin concentration [2]. The market offers, in addition to dried products, even semidry products, to limit the loss of the nutritional characteristics that occur in the fully dried product. The semidry product is a special category of dehydrated products that have a residual water content of about $30 \%$; for this reason, nutritional product characteristics are better preserved. In recent years, there has been an increase in research concerning the new hybrid drying technologies to improve food quality, as heat pump drying, fluidized bed drying, infrared drying, microwave and radio-frequency drying, freeze-drying, spray drying and refractance window drying minimize product degradation and yet produce a product with the desired water content $[10,24]$. 
The aim of this study was a comparison of drying processes, convective oven drying and sun-drying of cherry tomatoes. In the EU, cherry tomatoes are cultivated and processed as dried products which can reduce waste and increase sustainability. The following tests were carried out in a pilot plant, using different temperatures and open-air natural sun drying, monitoring some of the basic chemical parameters, the trends of the main nutrients in tomatoes during the drying process, and evaluating the sensorial characteristics of the products. The goal was to obtain semidry and dry products with a convective oven dryer with comparable nutritional and sensorial characteristics to those sun-dried.

\section{Materials and Methods}

\subsection{Raw Material}

A total of $50 \mathrm{~kg}$ of tomato fruit (Lycopersicon esculentum L. cv. Cherry) was purchased from a local market. Tomatoes with uniform size were cut into two parts, and then salt ( $1 \mathrm{~g} / 50 \mathrm{~g}$ fresh weight) was added before the treatment.

\subsection{Chemicals}

Ascorbic acid, 3,4,5-trihydroxybenzoic acid, fluorescein azodiisobutyramidine dihydrochloride and Trolox were purchased from Sigma Chemical Co. (St. Louis, MO, USA). All other chemicals were of analytical grade, and the solvents used for chromatography.

\subsection{Drying Process, Water Content and Water Activity $\left(a_{w}\right)$}

Tomato drying was performed using a pilot plant dryer (Società Italiana Essiccatoi, Milan, Italy) at three air temperatures, 50,60 , and $70{ }^{\circ} \mathrm{C}$, at a $1.5 \mathrm{~m} \mathrm{~s}^{-1}$ flow rate, or solar drying treatment, in order to obtain a final product with a residual water content of $15 \%$ for dry product and $30 \%$ for semidry product. The speed of drying, therefore, was directly related to the treatment temperature; higher temperatures lowered drying times. The drying rate was assessed as the ratio of the initial and final water content. The water in fresh and dried samples was measured by thermobalance (Gibertini Eurotherm, Novate Milanese, Italy). During the drying test, the samples were collected every $30 \mathrm{~min}$. For each sample, the $\mathrm{M}$ value (absolute humidity), $\mathrm{a}_{\mathrm{w}}$ and the moisture sorption isotherms were determined using a Aqualab vapor sorption analyzer (Pullman, WA, USA). Data interpolation were evaluated by the average error value (E\%) defined by Equation (1):

$$
\mathrm{E} \%=\frac{100}{\mathrm{~N}} \times \sum_{\mathrm{i}=1}^{\mathrm{N}} \times \frac{\mid \text { Xspe }- \text { Xprev } \mid}{\text { Xspe }}
$$

where $N$ represents the number of interpolated points, $X_{\text {spe }}$ the test point and $X_{\text {prev }}$ the point obtained using the mathematical model. Then, the Arrhenius law was applied to determine the temperature dependence of $\mathrm{a}_{\mathrm{w}}$ by Equation (2):

$$
\ln a_{w}=\ln a_{w 0}-\frac{\Delta \mathrm{Ha}}{\mathrm{RT}}
$$

where $a_{w}$ is the water activity, $R$ is the gas constant, and $T$ is the temperature. Through the Arrhenius law, was traced the value of desorption energy $\left(\Delta \mathrm{H}_{\mathrm{a}}\right)$. It was determined that $\Delta \mathrm{H}_{\mathrm{a}}$ was a function of absolute humidity (M), $\mathrm{M}$ value decreasing as $\Delta \mathrm{H}_{\mathrm{a}}$ value increased.

It calculated drying kinetics at different experimental conditions to a minimum value of $15 \%$ of residual water content. All the experiments were performed in triplicate.

\section{4. $p H$, Total Acidity and Total Soluble Solids}

Dried samples were diluted with distilled water $(1: 10 w / v)$ and homogenized with an Ultra-Turrax T25 homogenizer (Janke and Kunkel, Staufen, Germany) for 60 s; then the mixture was filtered with Whatman filter paper Grade 589. Titratable acidity (TA), total soluble solids (TSS), and $\mathrm{pH}$ were determined according to AOAC (1995) [25]. $\mathrm{pH}$ was measured using a HI 9025 pH meter equipped with a spear electrode FC 200 (Hanna 
Instruments). TA was determined using $0.1 \mathrm{~N}$ sodium hydroxide and phenolphthalein as an indicator and was expressed as\% malic acid, while TSS was measured with a hand refractometer (Mettler Toledo, Schwerzenbach, Switzerland) and expressed as ${ }^{\circ}$ Brix. All the analyses were made in triplicate.

\subsection{Ascorbic Acid}

Briefly, $5 \mathrm{~mL}$ of filtered juice obtained as above was poured into a flask and made up to $50 \mathrm{~mL}$ with $3 \%(w / v)$ metaphosphoric acid solution. An aliquot of the solution was filtered through a $0.45 \mu \mathrm{m}$ filter, and $20 \mu \mathrm{L}$ of this aliquot was injected into the HPLC. Ascorbic acid was determined by liquid chromatography using an SCL-10A, Shimadzu (Kyoto, Japan) equipped with two pumps (LC-10A), a control system (SCL-10A), a diode array detector (SPD-M10A), a C18 Alltima ODS Hypersil column $250 \times 4.6 \mathrm{~mm}$ I.D. (Milan, Italy) with a similarly packed pre-column. Tomato fruit samples of known weight were homogenized using Ultra Turrax. The homogenate was centrifuged for $5 \mathrm{~min}$ at $16,000 \times g$ at $4{ }^{\circ} \mathrm{C}$, and the supernatant was filtered under vacuum. The mobile phase was $0.002 \mathrm{M}$ phosphoric acid, and the UV detector wavelength was $260 \mathrm{~nm}$ [26]. The equation of the calibration curves obtained with the ascorbic acid standard was $y=661,852 x$ with $R^{2}=0.9961$. All the analyses were made in triplicate and are reported as $\mathrm{mg} / \mathrm{kg}$ dry matter (DM).

\subsection{Determination of Carotenoid Contents}

Three aliquots of dried tomato samples ( $5 \mathrm{~g}$ each) obtained from 10 fruits previously ground to a fine powder under liquid nitrogen were mixed for 20 min with $50 \mathrm{~mL}$ of extracting solvent (hexane/acetone/ethanol, 50:25:25, v/v). The organic phase containing carotenoids was recovered and then used for analyses after suitable dilution with hexane $(1: 10 \mathrm{v} / \mathrm{v})$. The total carotenoid determination was carried out on an aliquot of the hexane extract by measuring absorbance at $450 \mathrm{~nm}$ k on a Varian Cary 1E spectrophotometer (Mulgrave, VIC, Australia). Total carotenoids were calculated according to the method of Ritter and Purcell, using an extinction coefficient of $\alpha$-carotene of $\varepsilon=2505$. The analyses were performed in triplicate for each sample.

\subsection{Total Polyphenols Content}

Total polyphenols analysis was carried out according to Singleton and Rossi [27]. Briefly, $1 \mathrm{~mL}$ of the diluted and filtered sample obtained as above with distilled water was mixed with $1 \mathrm{~mL}$ Folin-Ciocâlteu reagent (FC), and after $3 \mathrm{~min}, 2.5 \mathrm{~mL}$ of sodium carbonate $\left(\mathrm{Na}_{2} \mathrm{CO}_{3}\right)$ was added. The solution was brought to a final volume of $25 \mathrm{~mL}$ and incubated in the dark for $1 \mathrm{~h}$. The absorbance was spectrophotometrically measured at $725 \mathrm{~nm}$ (PerkinElmer lambda $25 \mathrm{UV}$-vis). The equation of the calibration curves obtained with the gallic acid (3,4,5-trihydroxybenzoic acid) standard was $y=0.102 x$ with $R^{2}=0.9985$. The phenolic content was expressed as mg of gallic acid equivalents (GAE) per $100 \mathrm{~g}$ of dry matter. All the analyses were made in triplicate.

\subsection{Polyphenol Oxidase (PPO) Activity}

Polyphenol oxidase (PPO) was extracted from $20 \mathrm{~g}$ of dried sample in $100 \mathrm{~mL}$ of $0.1 \mathrm{M}$ phosphate buffer $\mathrm{pH} 7.0$, homogenized with an UltraTurrax T25 for $2 \mathrm{~min}$, and then centrifugated at $12,000 \times g$ for $20 \mathrm{~min}$ at $4{ }^{\circ} \mathrm{C}$. The sample was vacuum filtered with Whatman filter paper 589, and the crude extract was purified using tangential flow filtration (Merck Millipore, Fischer Scientific, Rodano (Mi), Italy). The activity of the filtered solution was measured at $\mathrm{pH} 4.5$ using catechol as the substrate [28]. The assay was conducted according to the method of Todaro et al. [29]. All the assays were made in triplicate, and enzymatic activity was expressed as enzymatic units $\left(\mathrm{mmol} \mathrm{min}-1 \mathrm{~g}^{-1}\right)$ per gram of dry matter. 


\subsection{Antioxidant Activity}

Tomato samples from different drying conditions were homogenized using a blender (Ultra Turrax T25 Janke e Kunkel, Staufen, Germany). The homogenate was centrifuged for $30 \mathrm{~min}$ at $10,000 \mathrm{rpm}$ and $4{ }^{\circ} \mathrm{C}$. The supernatant was separated from the pellet and finally filtered under vacuum. The sample was diluted with phosphate buffer $(1: 25-100, v / v)$ at $\mathrm{pH} 7.4$ prior to analysis. Antioxidant activity was determined by the ORAC assay that measures the scavenging of free radicals generated in the reaction mixture. The method was performed as described by Cao et al. [30], with some modifications [31,32]. The measurements were carried out on a Wallac 1420 Victor III 96-well plate reader (EG and Wallac, Turku, Finland) with a fluorescence filter (excitation $485 \mathrm{~nm}$, emission $535 \mathrm{~nm}$ ). Fluorescein $(116 \mathrm{nM})$ was the target molecule for free radical attack from $\alpha, \alpha$-azodiisobutyramidine dihydrochloride (AAPH, $153 \mathrm{mM}$ ) as the peroxyl radical generator. The reaction was conducted at $37^{\circ} \mathrm{C}$ and $\mathrm{pH} 7.0$ with Trolox $(1 \mu \mathrm{M})$ as the control standard and phosphate buffer as the blank. All solutions were freshly prepared prior to analysis, and results were reported as $\mu \mathrm{M}$ Trolox equivalents $/ 10 \mathrm{~g}$ of dry matter (DM). All the analyses were made in triplicate.

\subsection{Sensory Evaluation}

The determination of the sensory profile [33] was conducted by twenty-five judges recruited from students of the Di3A Department, Catania University. Candidates were submitted to preliminary tests to determine their sensory performance on basic tastes. A sensory profile was constructed using a selected panel of ten judges (ISO 2003a) trained over six sessions, who created, based on a frequency of citation of $70 \%$, a list of eighteen descriptors: 3 visual-based (color, shine, degree of dryness), 4 olfactory-based (salsa, tomato, baked, or off-odor), 3 taste (salty, bitter, sweet), 3 tactile in the mouth (juiciness, cohesiveness, adhesiveness), 4 flavor-based (tomato sauce flavor, tomato flavor, cooked flavor, off-flavor) and overall assessment, body (Table 1). The different descriptors were quantified using a nine-point intensity scale.

Table 1. Descriptors found for the sensory evaluation.

\begin{tabular}{cc}
\hline Descriptors & \\
\hline Visuals & Color \\
& Shine \\
& Dryness degree \\
Olfactory & Salsa smell \\
& Fresh tomato \\
& Baked \\
Taste & Off-odor \\
& Salty \\
& Bitter \\
Tactile in the mouth & Sweet \\
& Juiciness \\
& Cohesiveness \\
Flavor & Adhesiveness \\
& Tomato sauce \\
& Tomato \\
Overall assessment & Cooked \\
\hline
\end{tabular}

The working plan provided for the evaluation of samples in triplicate, which were presented to each judge in plastic dishes signed with a three-digit code. For all samples, the order of presentation was randomized for judging and for sitting. The evaluations were conducted in the laboratory of sensory analysis of Di3A of the University of Catania 
using FIZZ software for acquisition and processing of sensory data (FIZZ Biosystemes ver. $2.00 \mathrm{M}$, Couternon, France). A discontinuous scale from 1 (absence of the descriptor) to 9 (maximum intensity of the descriptor) was used for data [33].

\subsection{Statistical Analysis}

After extraction, all samples were fully dried and reweighed in order to report data on a DM basis. One-way analysis of variance followed by Tukey's post hoc test at $\alpha=0.05$ was performed using Matlab R2015a (MathWorks, Inc., Nutick, MA, USA). Several statistical models were applied to interpolate data with errors at the different temperatures.

\section{Results and Discussion}

\subsection{Kinetics of Drying and Desorption Isotherms}

Sun-drying was slower than the convection oven method, likely due to the atmospheric temperature being lower than that of the dryer. The speed of drying, therefore, is directly related to the treatment temperature; higher temperatures will lower drying times (Figure 1).

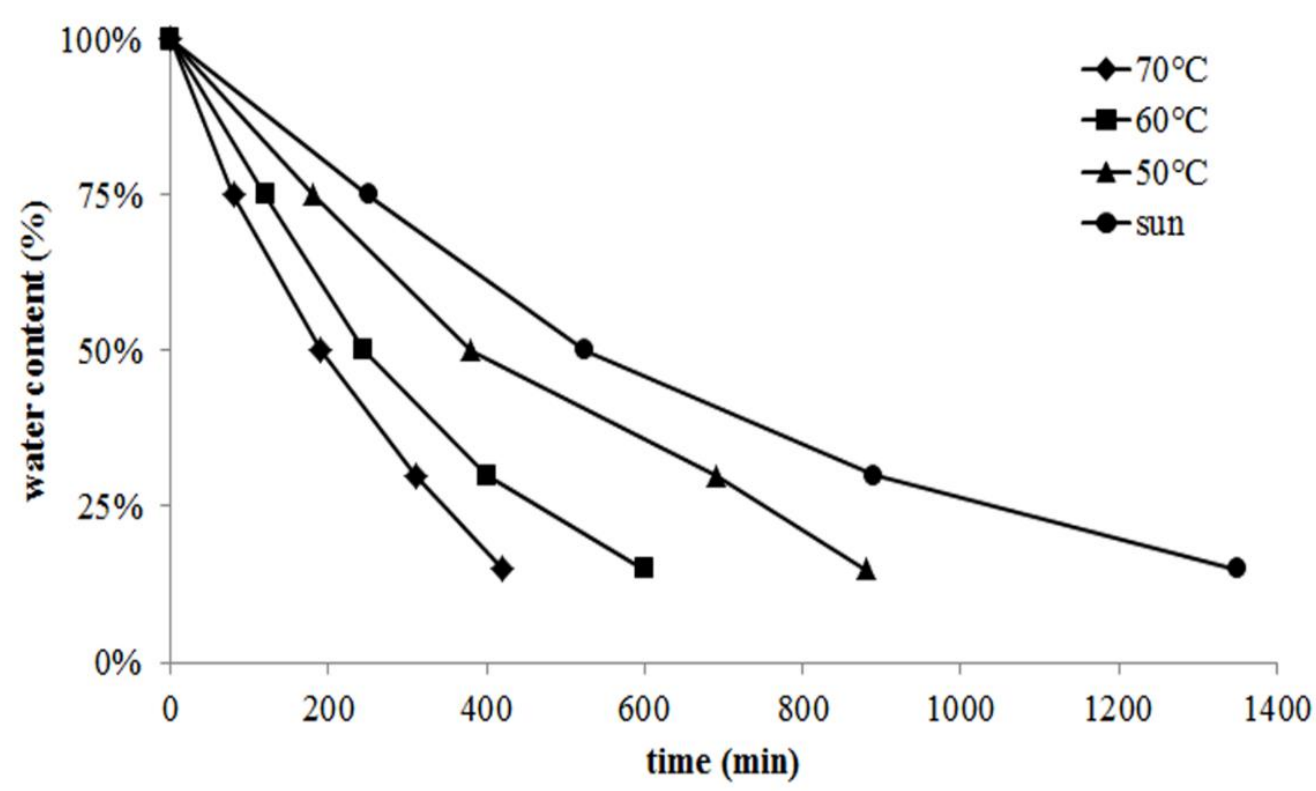

Figure 1. Kinetics of drying at different experimental conditions.

Figure 2 shows the evolution of absolute humidity during the process of drying at 50, 60 and $70{ }^{\circ} \mathrm{C}$. The experimental data were interpolated using a polynomial equation of second-order. During the drying process, the $\mathrm{a}_{\mathrm{w}}$ values were used to trace the desorption isotherms. This operation was carried out only for dried samples with the artificial method because the sun-dried samples were not subjected to stable temperatures over time, and it was not possible to draw the isotherms. The samples of known size and weight were sampled every $30 \mathrm{~min}$. For each sample, the $\mathrm{M}$ value (absolute humidity) and $\mathrm{a}_{\mathrm{w}}$ were calculated. The experimental data were subjected to secondary mathematical interpolations in order to trace the desorption isotherms. Several mathematical models shown in Table 2 were used to interpolate data samples. These included the Smith [34], GAB [3,4], IglesiasChirife [35], Chen [36], and Henderson [37] models.

Before applying the models, the isotherms were interpolated following a second degree polynomial obtaining the equations $y=0.000012 x^{2}+0.000878 x+0.908945, y=0.000006 x^{2}+$ $0.000238 x+0.927427$ and $y=0.000001 x^{2}+0.000042 x+0.915347$ with $R^{2}$ values of $0.94,0.98$ and 0.96 for 50,60 and $70{ }^{\circ} \mathrm{C}$, respectively. 


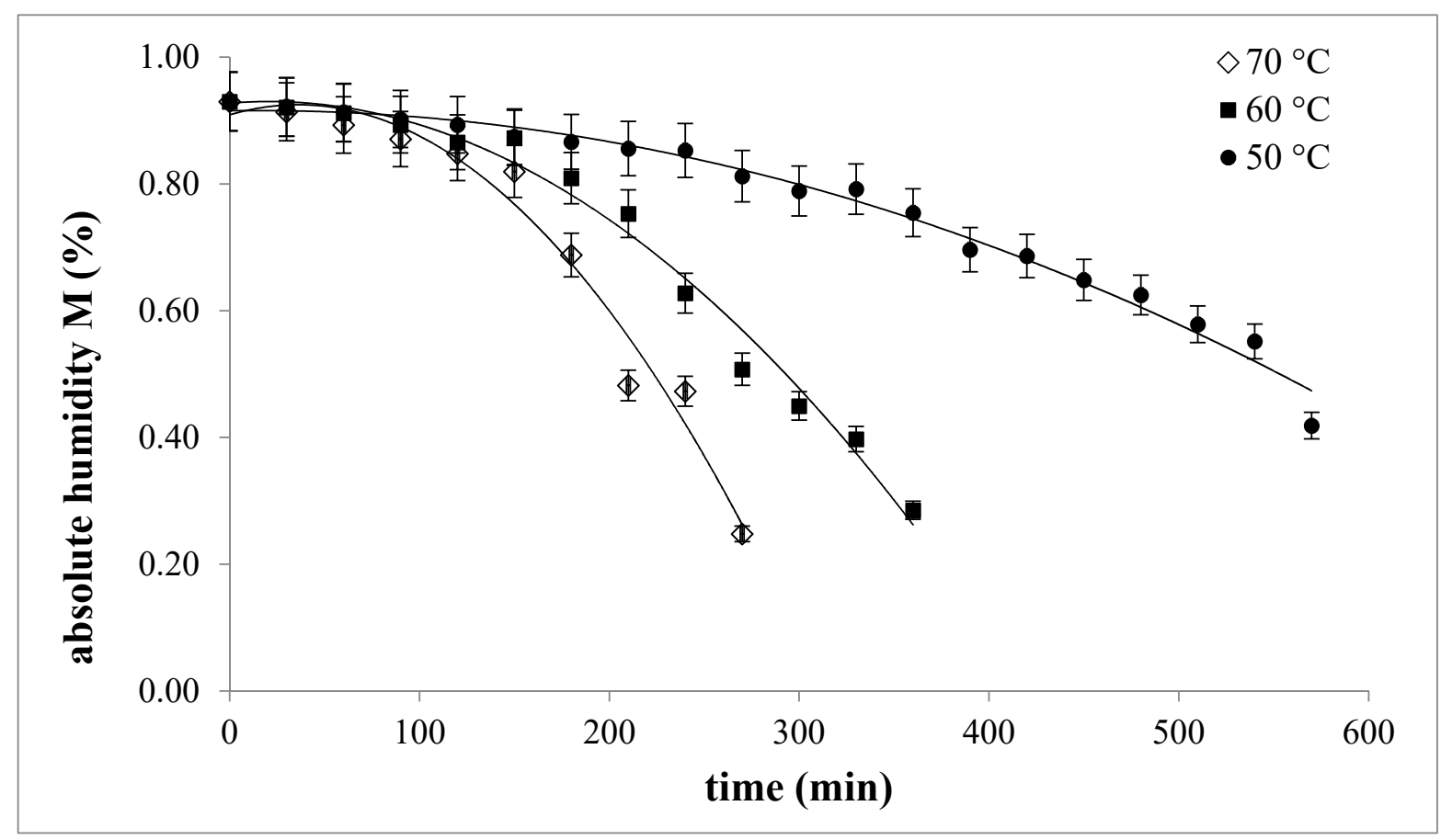

Figure 2. Trend of absolute humidity $(\mathrm{M})$ during the drying process.

Table 2. Models applied to interpolate data with errors at different temperatures.

\begin{tabular}{ccccc}
\hline \multirow{2}{*}{ Model Name } & Equation Formula & \multicolumn{3}{c}{ Error \% at Different $\mathbf{~}$} \\
\cline { 3 - 4 } & & $\mathbf{5 0}{ }^{\circ} \mathbf{C}$ & $\mathbf{6 0}{ }^{\circ} \mathbf{C}$ & $\mathbf{7 0}{ }^{\circ} \mathbf{C}$ \\
\hline Smith & $M=a+* \ln \left(1-a_{w}\right)$ & 5.0 & 4.7 & 5.0 \\
Gab & $\frac{a_{w}}{M}=\alpha a_{w}^{2}+\beta a_{w}+\gamma$ & 3.5 & 4.7 & 5.2 \\
Iglesias-Chirife & $M=a * \frac{a_{w}}{\left(1-a_{w}\right)}+b$ & 6.7 & 9.2 & 11.0 \\
Chen & $M=\frac{-\ln \left(-\ln \left(a_{w}\right)-\ln a\right)}{b}$ & 11.0 & 14.5 & 23.0 \\
Henderson & $M=\left[\frac{\ln \left(1-a_{w}\right)}{-K}\right]^{\frac{1}{N}}$ & 32.0 & 7.7 & 17.6 \\
\hline
\end{tabular}

The Smith and GAB models showed a good capability for interpolating at all three drying temperatures (Supplementary Figure S1). Among the tested models, Smith and GAB interpolated the data well, showing lower $\mathrm{E}$ values for each of the temperatures. Iglesias and Chirife [35] models, were suitable at $50{ }^{\circ} \mathrm{C}$ and $60^{\circ} \mathrm{C}$. In contrast, the Henderson [37] model well described the evolution of the isotherm at $60^{\circ} \mathrm{C}$. Peishi and Pei [38] models were not suitable at any temperature (data not showed). Ankabi et al. [3] reported that the GAB model was the best for the interpolation of similar data, as also reported by Giovannelli and Paradiso [2].

\section{2. $p H$, Total Acidity and Brix Values}

The $\mathrm{pH}$ values were stable during test drying, and, furthermore, there were no significant differences among experimental conditions. Brix values increased during the drying process as expected (Supplementary Table S1).

\subsection{Ascorbic Acid}

Ascorbic acid content decreased in all samples. This reduction was also reported by Lavelli et al. [39], Gahler et alt [40] and Dewanto et al. [19] and is probably due to the thermosensitivity of ascorbic acid. Figure 3 shows how the reduction of ascorbic acid was 
more pronounced in the sun-dried product, where the value decreased $49.2 \%$ from the initial value with generally significant differences from samples that were oven-dried at the three temperatures. This result is probably due to the combination of the processing time and sunlight exposure. The samples dried in the oven dryer showed a decrease in ascorbic acid content ranging between 18.5 and $30 \%$ for the slowest and highest temperature drying, respectively, with a few significant differences between samples dried at $50{ }^{\circ} \mathrm{C}$ and the samples dried at 60 or $70^{\circ} \mathrm{C}$.

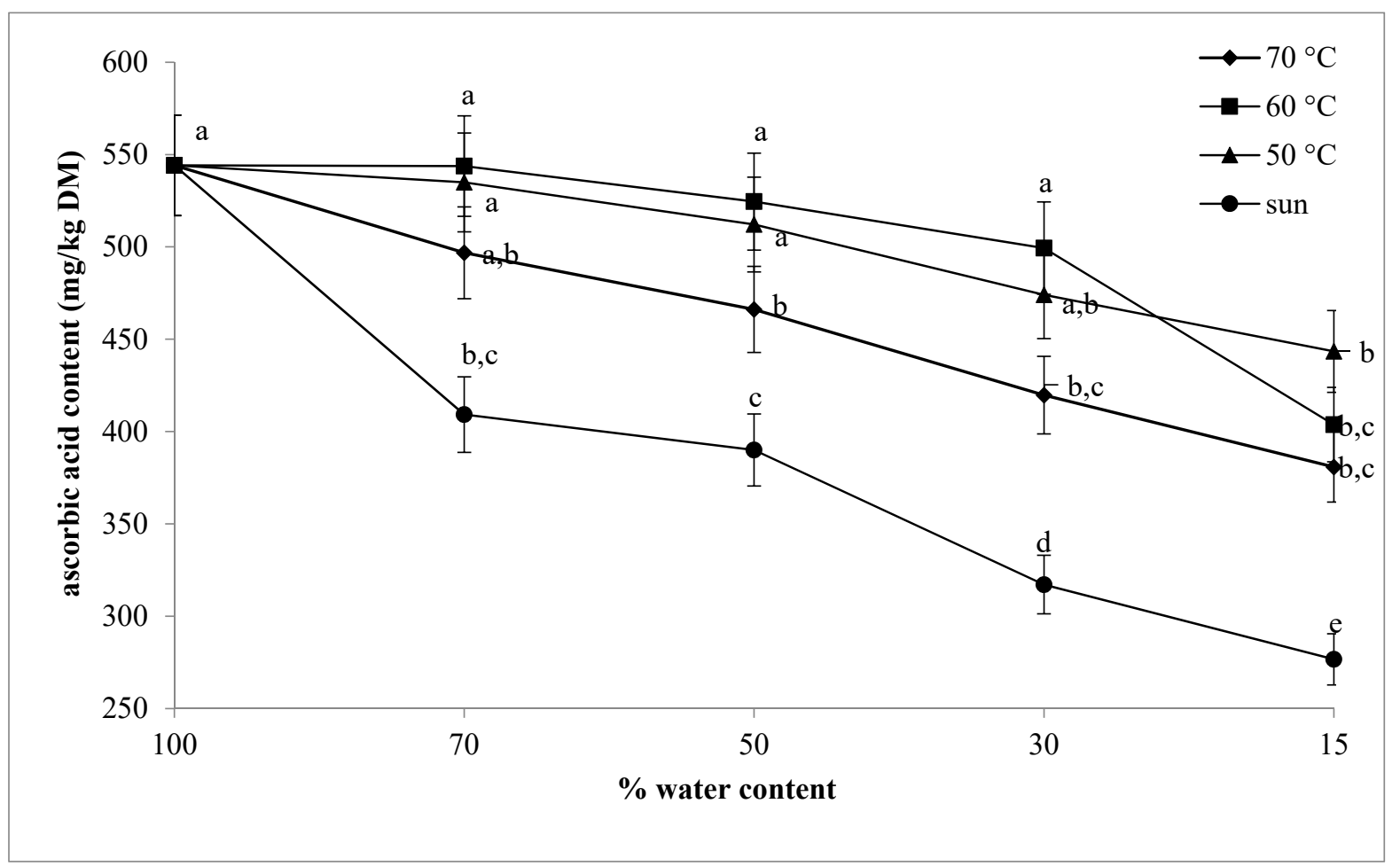

Figure 3. Ascorbic acid content with different drying conditions. Data points with different letters are statistically different by Tukey's test at $\alpha=0.05$.

\subsection{Carotenoid Contents}

The content of carotenoids was influenced by temperature and treatment duration (Supplementary Table S1). High-temperature treatment (cooking, drying, etc.) increases the extractability of carotenoids [30]. In our study, the higher content of carotenoids $(0.71 \mathrm{mg} / \mathrm{g} \mathrm{DM})$ was in the product dried at $70{ }^{\circ} \mathrm{C}$. In the products dried at $50{ }^{\circ} \mathrm{C}$, the content was almost stable with a slight reduction at the end of the process (from 0.23 to $0.19 \mathrm{mg} / \mathrm{g}$ DM). The same trend was also highlighted by Toor and Savage [16]. The comparison of the sample obtained at $60^{\circ} \mathrm{C}$ with the sun-dried sample showed similar carotenoid content (0.56 and $0.53 \mathrm{mg} / \mathrm{g} \mathrm{DM}$, respectively) at all stages with no significant difference.

\subsection{Total Polyphenols and PPO Activity}

Total polyphenols increased during the drying process in the semidry product $(30 \%$ of final water content) obtained at higher temperatures $\left(60^{\circ} \mathrm{C}\right.$ and $\left.70{ }^{\circ} \mathrm{C}\right)$ in contrast to the dry product (Figure 4). This is possibly due to the collapse of the plant matrix [30], increasing the free polyphenol fraction [16].

In the sun-dried tissue, the polyphenol content increased at $15 \%$ water content. At low temperatures $\left(50{ }^{\circ} \mathrm{C}\right)$, there was a reduction of total polyphenol content compared to the fresh product. This was probably due to the increase of PPO activity which has an optimum temperature at $40{ }^{\circ} \mathrm{C}$ [22]. 


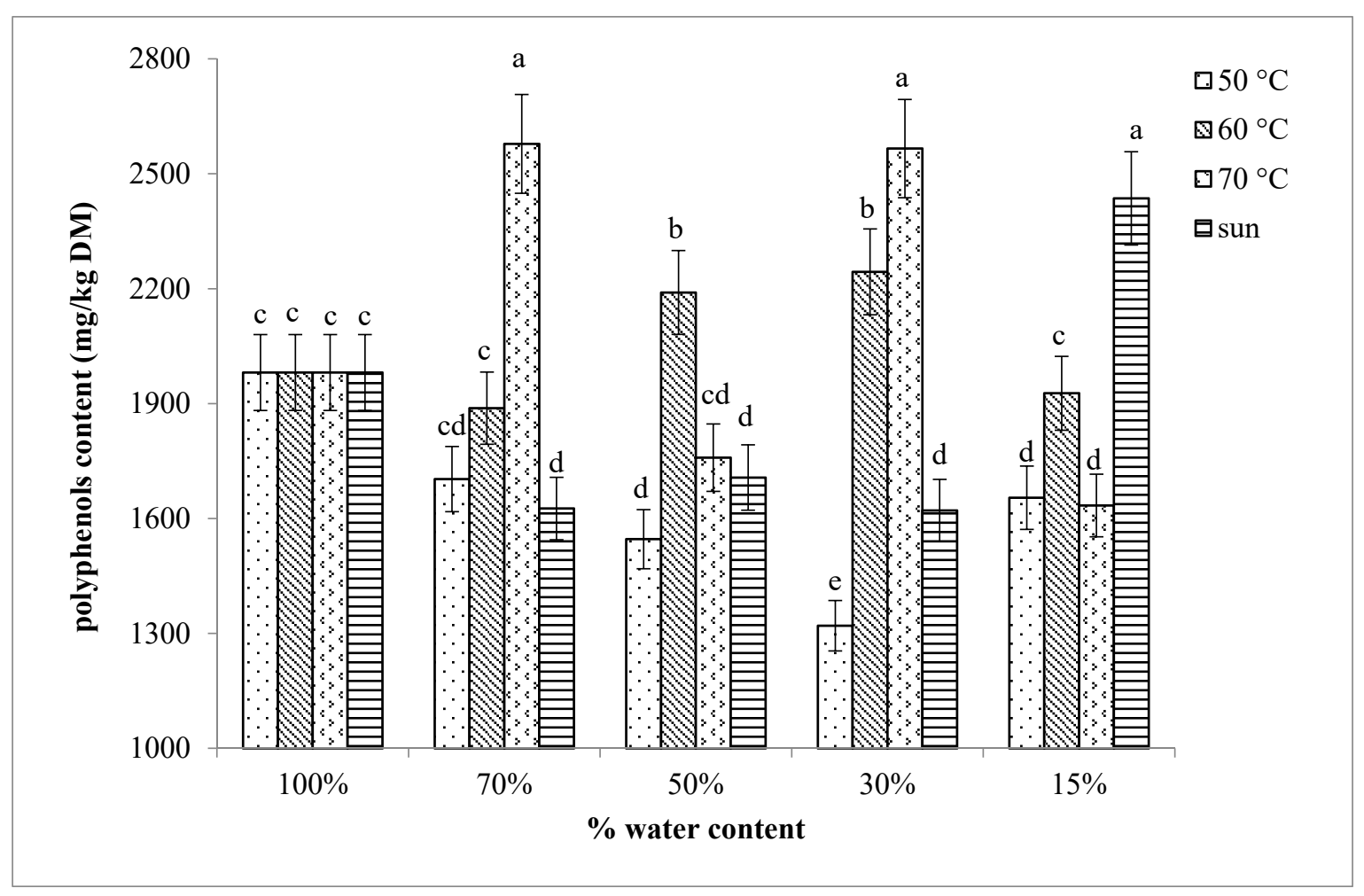

Figure 4. Polyphenol content at drying conditions. Bars are means with standard errors, and those with different letters are statistically different by Tukey's test at $\alpha=0.05$.

PPO activity was very high in the products dried at $50{ }^{\circ} \mathrm{C}(3.35 \mathrm{U} / \mathrm{mg}$ protein), and the lowest value was in the tissue dried at $70{ }^{\circ} \mathrm{C}(1.03 \mathrm{U} / \mathrm{mg}$ protein) (Supplemental Figure S2). This result may be related, in addition to temperature, even to the content of total polyphenol, which represents the substrate of the enzyme.

\subsection{Total Antioxidant Activity}

The different drying temperatures greatly influenced the evolution of ORAC values (Table 3). In the tissue dried at $70{ }^{\circ} \mathrm{C}$, there was an increase in antioxidant activity early during the drying process. This phenomenon, likely due to an initially higher concentration of carotenoids and has been widely reported $[2,15,19,38]$.

Table 3. Antioxidant activity (ORAC value expressed as $\mu \mathrm{mol} T E / 100 \mathrm{~g} D M$ ) from the different drying treatments.

\begin{tabular}{ccccc}
\hline $\mathbf{\%} \mathbf{H}_{\mathbf{2}} \mathbf{O}$ & $\mathbf{5 0}{ }^{\circ} \mathbf{C}$ & $\mathbf{6 0}{ }^{\circ} \mathbf{C}$ & $\mathbf{7 0}^{\circ} \mathbf{C}$ & Sun \\
\hline 100 & $3008 \pm 217 \mathrm{~b}^{\mathrm{z}}$ & $3008 \pm 217 \mathrm{~b}$ & $3008 \pm 217 \mathrm{~b}$ & $3008 \pm 217 \mathrm{~b}$ \\
70 & $1537 \pm 101 \mathrm{e}$ & $2220 \pm 154 \mathrm{c}$ & $1833 \pm 46 \mathrm{~d}$ & $823 \pm 30 \mathrm{~g}$ \\
50 & $772 \pm 41 \mathrm{~g}$ & $2029 \pm 204 \mathrm{c}$ & $2439 \pm 133 \mathrm{c}$ & $758 \pm 53 \mathrm{~g}$ \\
30 & $1263 \pm 46 \mathrm{f}$ & $1680 \pm 35 \mathrm{~d}$ & $2171 \pm 82 \mathrm{c}$ & $978 \pm 11 \mathrm{~g}$ \\
15 & $1707 \pm 47 \mathrm{~d}$ & $1908 \pm 32 \mathrm{~d}$ & $3488 \pm 146 \mathrm{a}$ & $1859 \pm 91 \mathrm{~d}$ \\
\hline
\end{tabular}

$\overline{\mathrm{z}}$ Values followed by different letters are statistically different by Tukey's test at $\alpha=0.05$.

\subsection{Sensory Evaluation}

For the tissues dried at lower temperatures $\left(50{ }^{\circ} \mathrm{C}\right.$ and $\left.60^{\circ} \mathrm{C}\right)$ and in the sun-dried products, there was a reduction of attributes (Figure 5). Analysis of variance indicated significant differences by drying treatment or temperature on sensory attributes: shine, dryness degree, cooked smell, salt, bitter, sweet, juiciness, cooked flavor and off-flavor. They were no significant differences for descriptors like color, tomato sauce smell, tomato smell, off-odor, cohesiveness, adhesion, tomato sauce flavor and tomato flavor. 


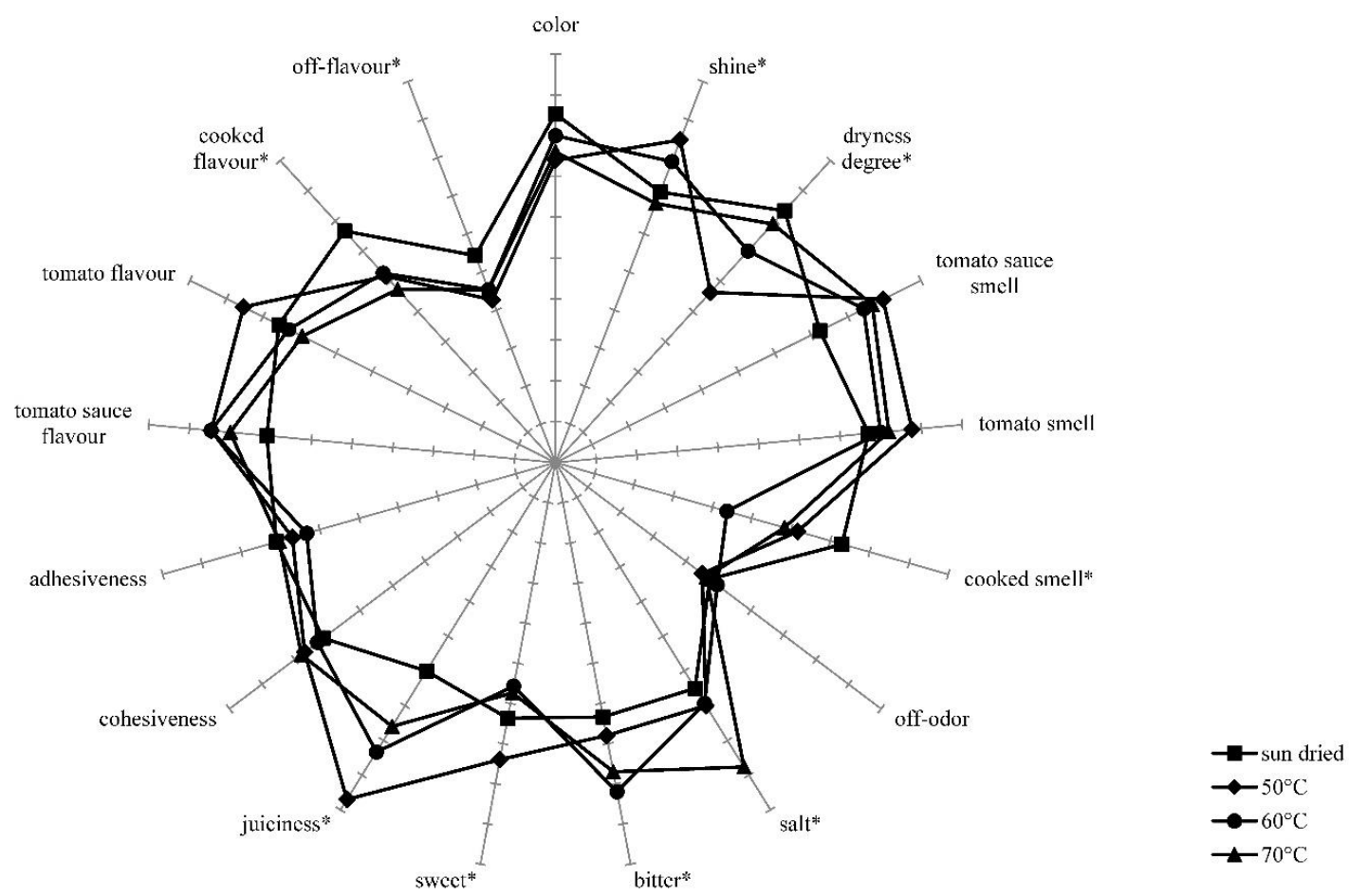

Figure 5. Mean sensory profile of tomato dried at different conditions. The symbol * indicates statistically significant differences among samples at $p \leq 0.05$.

\section{Conclusions}

The time required to reach a water content of $15 \%$ from the initial water content at the various drying temperatures was between 420 and $1400 \mathrm{~min}$. The Brix values increased during the drying period, making the samples more palatable from the sensory point of view, but there was a significant decrease in the ascorbic acid content. The content of carotenoids, of which the most important is lycopene, had greater extractability in the dried product at $70{ }^{\circ} \mathrm{C}$ compared to the other drying treatment, undoubtedly a very encouraging aspect from the nutraceutical point of view, in concert with an increase in the total polyphenol content. The sensory evaluation of the samples revealed a good leveling of characteristics such as bitterness, sweetness and consistency. The optimal treatment was determined to be at $60^{\circ} \mathrm{C}$, relative to the chemical parameters and the treatment time. In particular, the polyphenol and ascorbic acid content was comparable to sundried products, recognized by consumers as typical. The best drying effect on antioxidant activity was for the samples dehydrated at $70{ }^{\circ} \mathrm{C}$, but dehydrated at $60{ }^{\circ} \mathrm{C}$ was also comparable to the products dried in the sun. As for the sensory profile, all the treatments tested were acceptable. The hygienic conditions that can be achieved in a cabinet dryer and the best nutritional values compared to sun-dried products encourage the use of the dryers.

Supplementary Materials: The following are available online at https:/ / www.mdpi.com/2311-752 $4 / 7 / 3 / 40 /$ s1.

Author Contributions: Conceptualization, D.P., A.T.; formal analysis V.A., D.P., S.V., R.P., A.T.; data curation, R.P., A.T.; writing—original draft preparation, A.T.; writing—review and editing, V.A., D.P., S.V., R.P., A.T. All authors have read and agree to the published version of the manuscript.

Funding: This research received no external funding.

Acknowledgments: Thanks to Spagna for his advice on drying technology, to C.M. Lanza and A. Mazzaglia for their advice on sensory analyses.

Conflicts of Interest: The authors have no advantage, financial or otherwise, and are not in a conflict of interest with respect to this publication. 


\section{References}

1. Togrul, I.T.; Pehlivan, D. Mathematical modelling of solar drying of apricots in thin layers. J. Food Eng. 2002, 55, 209-216. [CrossRef]

2. Giovanelli, G.; Paradiso, A. Stability of dried and intermediate moisture tomato pulp during storage. J. Agric. Food Chem. 2002, 50, 7277-7281. [CrossRef]

3. Akanbi, C.T.; Adeyemi, R.S.; Ojo, A. Drying characteristics and sorption isotherm of tomato slices. J. Food Eng. 2006, 73, 157-163. [CrossRef]

4. Lewicki, P.P.; Michaluk, E. Drying of tomato pretreated with calcium. Dry Technol. 2004, 22, 1813-1827. [CrossRef]

5. Lewicki, P.P.; Vu Le, H.; Pomarańska-Łazuka, W. Effect of pre-treatment on convective drying of tomatoes. J. Food Eng. 2002, 54, 141-146. [CrossRef]

6. Sacilik, K.; Keskin, R.; Elicin, A.K. Mathematical modelling of solar tunnel drying of thin layer organic tomato. J. Food Eng. 2006, 73, 231-238. [CrossRef]

7. Kross, R.K.; Cavalcanti Mata, M.E.R.M.; Duarte, M.E.M.; Silveira, V., Jr. Drying kinetic of tomatoes submits to previous osmotic treatment. In Proceedings of the 14th International Drying Symposium, São Paulo, Brazil, 22-25 August 2004; pp. $22-25$.

8. Doymaz, I.; Kipcak, A.S. Effect of pre-treatment and air temperature on drying time of cherry tomato. J. Therm. Eng. 2018, 4, 1648-1655.

9. Doymaz, I. Drying kinetics of black grapes treated with different solutions. J. Food Eng. 2006, 76, 212-217. [CrossRef]

10. Doymaz, I. Air-drying characteristics of tomatoes. J. Food Eng. 2007, 78, 1291-1297.

11. Kaur, R.; Kaur, K.; Ahluwalia, P. Effect of drying temperatures and storage on chemical and bioactive attributes of dried tomato and sweet pepper. LWT-Food Sci. Technol. 2020, 117, 108604. [CrossRef]

12. Mrkìc, V.; Cocci, E.; Rosa, M.D.; Sacchetti, G. Effect of drying conditions on bioactive compounds and antioxidant activity of broccoli (Brassica oleracea L.). J. Sci. Food Agric. 2006, 86, 1559-1566. [CrossRef]

13. Nguyen, M.L.; Schwartz, S.J. Lycopene Chemical and Biological Propertie. Food Technol. 1999, 53, $38-45$.

14. Manzocco, L.; Calligaris, S.; Mastrocola, D.; Nicoli, M.C.; Lerici, C.R. Review of non-enzymatic browning and antioxidant capacity in processed foods. Trends Food Sci. Technol. 2000, 11, 340-346. [CrossRef]

15. Nicoli, M.C.; Anese, M.; Parpinel, M. Influence of processing on the antioxidant properties of fruit and vegetables. Trends Food Sci. Technol. 1999, 10, 94-100. [CrossRef]

16. Toor, R.K.; Savage, G.P. Effect of semi-drying on the antioxidant components of tomatoes. Food Chem. 2006, 94, 90-97. [CrossRef]

17. Toor, R.K.; Lister, C.E.; Savage, G.P. Antioxidant activities of New Zealand grown tomatoes. Int. J. Food Sci. Nutr. 2005, 56, 597-605. [CrossRef]

18. Shi, J.; Maguer, M.; Le Kakuda, Y.; Liptay, A.; Niekamp, F. Lycopene degradation and isomerization in tomato dehydration. Food Res. Int. 2006, 32, 15-21. [CrossRef]

19. Dewanto, V.; Xianzhong, W.; Adom, K.K.; Liu, R.H. Thermal processing enhances the nutritional value of tomatoes by increasing total antioxidant activity. J. Agric. Food Chem. 2002, 50, 3010-3014. [CrossRef]

20. Rao, M.A.; Lee, C.Y.; Katz, J.; Cooley, H.J. A Kinetic Study of the Loss of Vitamin C, Color, and Firmness during Thermal Processing of Canned Peas. J. Food Sci. 1981, 46, 636-637. [CrossRef]

21. Zanoni, B.; Peri, C.; Nani, R.; Lavelli, V. Oxidative heat damage of tomato halves as affected by drying. Food Res. Int. 1998, 31, 395-401. [CrossRef]

22. Spagna, G.; Barbagallo, R.N.; Chisari, M.; Branca, F. Characterization of a tomato polyphenol oxidase and its role in browning and lycopene content. J. Agric. Food Chem. 2005, 53, 2032-2038. [CrossRef]

23. Hidalgo, A.; Pompei, C. Hydroxymethylfurfural and furosine reaction kinetics in tomato products. J. Agric. Food Chem. 2000, 48, 78-82. [CrossRef]

24. Jeyaprakash, S.; Heffernan, J.E.; Driscoll, R.H.; Frank, D.C. Impact of drying technologies on tomato flavor composition and sensory quality. LWT-Food Sci. Technol. 2020, 120, 108888. [CrossRef]

25. AOAC. Official Methods of Analysis of Association of Official Analytical Chemistry, 16th ed.; Association of Official Analytical Chemists: Washington, DC, USA, 1995.

26. Rapisarda, P.; Intelisano, S. Sample preparation for vitamin C analysis of pigmented orange juices. Ital. J. Food Sci. 1996, 8, 251-256.

27. Singleton, V.L.; Rossi, J.A. Colorimetry of Total Phenolics with Phosphomolybdic-Phosphotungstic Acid Reagents. Am. J. Enol. Vitic. 1965, 16, 144-158.

28. Mazzocco, F.; Pifferi, P.G. An improvement of the spectrophotometric method for the determination of tyrosinase catecholase activity by Besthorn's hydrazone. Anal. Biochem. 1976, 72, 643-647. [CrossRef]

29. Todaro, A.; Peluso, O.; Catalano, A.E.; Mauromicale, G.; Spagna, G. Polyphenol oxidase activity from three sicilian artichoke [Cynara cardunculus L. Var. scolymus L. (Fiori)] cultivars: Studies and technological application on minimally processed production. J. Agric. Food Chem. 2010, 58, 1714-1718. [PubMed]

30. Cao, G.; Alessio, H.M.; Cutler, R.G. Oxygen-radical absorbance capacity assay for antioxidants. Free Radic. Biol. Med. 1993, 14, 303-311. [CrossRef]

31. Lo Scalzo, R.; Todaro, A.; Rapisarda, P. Methods used to evaluate the peroxyl (ROO.) Radical scavenging capacities of four common antioxidants. Eur. Food Res. Technol. 2012, 235, 1141-1146. [CrossRef] 
32. Todaro, A.; Cavallaro, R.; La Malfa, S.; Continella, A.; Gentile, A.; Fischer, U.A.; Carle, R.; Spagna, G. Anthocyanin profile and antioxidant activity of freshly squeezed pomegranate (Punica granatum L.) Juices of Sicilian and Spanish provenances. Ital. J. Food Sci. 2016, 28, 464-479.

33. Pagliarini, E. Valutazione Sensoriale: Aspetti Teorici, Pratici e Metodologici; Hoepli: Milan, Italy, 2002.

34. Smith, S.E. The sorption of water vapor by high polymers. J. Am. Chem. Soc. 1947, 69, 646-651. [CrossRef]

35. Iglesias, H.A.; Chirife, J. An Empirical Equation for Fitting Water Sorption Isotherms of Fruits and Related Products. Can. Inst. Food Sci. Technol. J. 1978, 11, 12-15. [CrossRef]

36. Chen, C.S. Water Activity-Concentration Models for Solutions of Sugars, Salts and Acids. J. Food Sci. 1989, 54, 1318-1321. [CrossRef]

37. Henderson, S.M. A basic concept of equilibrium moisture. Agric. Eng. 1952, 33, 29-32.

38. Peishi, C.; Pei, D.C.T. A mathematical model of drying processes. Int. J. Heat Mass Transf. 1989, 32, 297-310. [CrossRef]

39. Lavelli, V.; Hippeli, S.; Peri, C.; Elstner, E.F. Evaluation of radical scavenging activity of fresh and air-dried tomatoes by three model reactions. J. Agric. Food Chem. 1999, 47, 3826-3831. [CrossRef] [PubMed]

40. Gahler, S.; Otto, K.; Böhm, V. Alterations of Vitamin C, Total Phenolics, and Antioxidant Capacity as Affected by Processing Tomatoes to Different Products. J. Agric. Food Chem. 2003, 51, 7962-7968. [CrossRef] [PubMed] 